\title{
Clinical status determines the efficacy of salivary and nasopharyngeal samples for detection of SARS-CoV-2
}

\author{
Gargi S. Sarode ${ }^{1} \cdot$ Sachin C. Sarode ${ }^{1}$ (D) Namrata Sengupta ${ }^{1} \cdot$ Amol R. Gadbail $^{2} \cdot$ Shailesh Gondivkar $^{3}$. \\ Nilesh Kumar Sharma ${ }^{4}$. Shankargouda Patil ${ }^{5}$
}

Received: 26 September 2020 / Accepted: 7 October 2020 / Published online: 12 October 2020

(C) Springer-Verlag GmbH Germany, part of Springer Nature 2020

Recently, salivary samples have been widely investigated for the detection of SARS-CoV-2 RNA with variable success rate [1-9]. The rationale claims that the virus particles possibly come from the respiratory system and infected salivary glands [1]. Proposed advantages are less-invasive, convenience, selfcollection, and minimum risk of cross infection [2]. To draw a meaningful conclusion in this regard, the most important study design would be a comparative cross-sectional analysis of salivary and nasopharyngeal samples (NPSs) in the detection of SARS-CoV-2 RNA with a cycle threshold value. Hence, we decided to critically analyze the results of published papers with such a study design.

We searched PubMed, SCOPUS, and Web of Science databases with keywords such as COVID-19, SARS-CoV-2, saliva, and nasopharyngeal swab in various permutations and combinations to retrieve the papers exclusively on the comparative analysis of saliva and NPS for detection of SARS-CoV-2 RNA using RT-PCR. After a thorough literature search, we could able to shortlist a total of nine studies from the literature [1-9]. Data such as sample size, disease

Sachin C. Sarode

drsachinsarode@gmail.com

1 Department of Oral Pathology and Microbiology, Dr. D.Y. Patil Dental College and Hospital, Dr. D.Y. Patil Vidyapeeth, Sant-Tukaram Nagar, Pimpri, Pune, MH 411018, India

2 Department of Dentistry, Indira Gandhi Government Medical College and Hospital, Nagpur, Maharashtra, India

3 Department of Oral Medicine and Radiology, Government Dental College \& Hospital, Nagpur, Maharashtra, India

4 Cancer and Translational Research Lab, Dr. D.Y. Patil Biotechnology \& Bioinformatics Institute, Dr. D.Y. Patil Vidyapeeth, Pune, Maharashtra 411033, India

5 Division of Oral Pathology, Department of Maxillofacial Surgery and Diagnostic Sciences, College of Dentistry, Jazan University, Jazan, Saudi Arabia status, detection rate, and cycle threshold value were retrieved. (Table 1) All the studies projected saliva as potential sampling material for the detection and diagnosis of SARS-CoV-2 RNA using RT-PCR.

One interesting trend apprehended our attention is the detection rate and cycle threshold values in symptomatic and asymptomatic patients. The categorization and characterization of the symptomatic and asymptomatic status of the patient were available in four $[1,4,5,9]$ and two [2, 7] cases, respectively. In asymptomatic cases, the sensitivity and detection rate was more in salivary samples as compared to NPS [2, 7]. Moreover, the cycle threshold values were comparatively low in salivary samples depicting high viral load in the oral cavity, whereas studies on symptomatic patients showed better results in NPS with high detection rate and low cycle threshold value as compared to salivary samples $[1,4,5,9]$. This discriminatory result between symptomatic and asymptomatic cases is highly intriguing; however, proper cognizance of this fact has not been taken in the literature.

The majority of the symptomatic SARS-CoV-2 positive cases show respiratory symptoms in the form of coughing, sneezing, and breathlessness, suggesting viral localization in the nasal and respiratory tract [3]. Hence, we envisaged that NPS is the most representative sample in the case of symptomatic cases and thus responsible for high sensitivity and detection rate. On the contrary, in asymptomatic cases, NPS could not be a representative sample (probably due to absent or limited viral localization) for the detection of SARS-CoV2. This contention is also supported by the lower cycle threshold for asymptomatic patients salivary samples and symptomatic patients NPS samples reported in the present analysis. Although this explanation is highly conceivable and is supported by the data reported in the literature, future studies are warranted in this direction with the appropriate characterization of the study samples into symptomatic and asymptomatic cases. Looking at this discriminative trend, prescription of saliva samples for asymptomatic cases and NPS for 
Table 1 Details of the comparative studies on saliva and nasopharyngeal specimens in detection of SARS-CoV-2 infection

\begin{tabular}{|c|c|c|c|c|c|}
\hline Sr. No. & Author & Sample size & Patient status & Detection rate & Mean Ct value \\
\hline 1. & Procop et al. [1] & 216 & Symptomatic & NPS, $10.3 \%$; saliva, $5.2 \%$; both, $84.5 \%$ & $\begin{array}{l}\text { NPS: } 20.55( \pm 5.36) \\
\text { Saliva: } 24.16( \pm 4.80)\end{array}$ \\
\hline 2. & Rao et al. [2] & 217 & Asymptomatic & Saliva, 93.1\%; NPS, 52.5\% & $\begin{array}{l}\text { NPS: } 33.2 \\
\text { Saliva: } 30.6\end{array}$ \\
\hline 3. & Jamal et al. [3] & 91 & Mixed & Saliva, $72 \%$; NPS, $89 \%$ & NA \\
\hline 4. & Landry et al. [4] & 124 & Symptomatic & NPS, $94.3 \%$; saliva, $85.7 \%$ & $\begin{array}{l}\text { NPS: } 33.68 \\
\text { Saliva: } 37.62\end{array}$ \\
\hline 5. & Vaz et al. [5] & 155 & Symptomatic & NPS, $45.8 \%$; saliva, $43.22 \%$ & NA \\
\hline 6. & Sutjpto et al. [6] & 105 & $\begin{array}{l}\text { Active: } 73 \\
\text { Negative: } 32\end{array}$ & NPS, $85 \%$; saliva, $38-52 \%$ & $\begin{array}{l}<7 \text { days: NPS, 24.05; saliva: } 32.49 \\
>7 \text { days: NPS, 32.20; saliva: } 30.98\end{array}$ \\
\hline 7. & Yokota et al. [7] & 1924 & Asymptomatic & NPS, $86 \%$; saliva, $92 \%$ & NA \\
\hline 8. & Williams et al. [8] & 622 & NA & $\begin{array}{l}\text { NPS: } 39 / 622(6.3 \%) \\
\text { Saliva: } 33 / 39(84.6 \%)\end{array}$ & Significantly lower in NPS than saliva \\
\hline 9. & Iwasaki et al. [9] & 76 & $\begin{array}{l}\text { Symptomatic positive: } 10 \\
\text { Suspicious negative: } 66\end{array}$ & $\begin{array}{l}\text { Both: } 8 \text { out of } 10 \text { patients } \\
\text { NPS: } 1 \text { out of } 10 \text { patients } \\
\text { Saliva: } 1 \text { out of } 10 \text { patients }\end{array}$ & $\begin{array}{l}\text { NPS: } 26.5( \pm 8.1) \\
\text { Saliva: } 30.6( \pm 4.6)\end{array}$ \\
\hline
\end{tabular}

NPS nasopharyngeal swab, $C t$ cycle threshold, $N A$ not available

symptomatic cases would be a valuable recommendation subject to validation in future randomized prospective studies. This will not only enhance the detection rate but also help in controlling the spread of the virus through the "test, trace and isolate, support" approach.

\section{Compliance with ethical standards}

Conflict of interest The authors declare that they have no conflict of interest.

Ethical approval This article does not contain any studies with human participants or animals performed by any of the authors.

Informed consent For this type of study, formal consent is not required.

\section{References}

1. Procop GW, Shrestha NK, Vogel S, Van Sickle K, Harrington S, Rhoads DD, Rubin BP, Terpeluk P (2020) A direct comparison of enhanced saliva to nasopharyngeal swab for the detection of SARSCoV-2 in symptomatic patients [published online ahead of print, 2020 Sep 3]. J Clin Microbiol. https://doi.org/10.1128/JCM.01946-20

2. Rao M, Rashid FA, Sabri FS, Jamil NN, Zain R, Hashim R, Amran F, Kok HT, Samad MA, Ahmad N (2020) Comparing nasopharyngeal swab and early morning saliva for the identification of SARSCoV-2 [published online ahead of print, 2020 Aug 6]. Clin Infect Dis. https://doi.org/10.1093/cid/ciaa1156

3. Jamal AJ, Mohammad M, Coomes E, Powis J, Li A, Paterson A, Anceva-Sami S, Barati S, Crowl G, Faheem A, Farooqi L (2020,
2020) Sensitivity of nasopharyngeal swabs and saliva for the detection of severe acute respiratory syndrome coronavirus 2 (SARSCoV-2) [published online ahead of print, 2020 Jun 25]. Clin Infect Dis. https://doi.org/10.1093/cid/ciaa848

4. Landry ML, Criscuolo J, Peaper DR (2020) Challenges in use of saliva for detection of SARS CoV-2 RNA in symptomatic outpatients [published online ahead of print, 2020 Jul 31]. J Clin Virol 130: 104567. https://doi.org/10.1016/j.jcv.2020.104567

5. Vaz SN, de Santana DS, Netto EM, Pedroso C, Wang WK, Santos FD, Brites C (2020) Saliva is a reliable, non-invasive specimen for SARS-CoV-2 detection [published online ahead of print, 2020 Aug 31]. Braz J Infect Dis. https://doi.org/10.1016/j.bjid.2020.08. 001

6. Sutjipto S, Lee PH, Tay JY, Mendis SM, Abdad MY, Marimuthu K, Ng OT, Lin C, Chan M, Soon M, Lin RT (2020) The effect of sample site, illness duration and the presence of pneumonia on the detection of SARS-CoV-2 by real-time reverse-transcription PCR. Open Forum Infect Dis. https://doi.org/10.1093/ofid/ofaa335

7. Yokota I, Shane PY, Okada K, Unoki Y, Yang Y, Inao T, Sakamaki K, Iwasaki S, Hayasaka K, Sugita J, Nishida M (2020) Mass screening of asymptomatic persons for SARS-CoV-2 using saliva.2020. https://ssrn.com/abstract=3668435

8. Williams E, Bond K, Zhang B, Putland M, Williamson DA (2020) Saliva as a non-invasive specimen for detection of SARS-CoV-2. J Clin Microbiol 58. https://doi.org/10.1128/JCM.00776-20

9. Iwasaki S, Fujisawa S, Nakakubo S, Kamada K, Yamashita Y, Fukumoto T, Sato K, Oguri S, Taki K, Senjo H, Sugita J (2020) Comparison of SARS-CoV-2 detection in nasopharyngeal swab and saliva. J Infect 81(2):e145-e147. https://doi.org/10.1016/j.jinf. 2020

Publisher's note Springer Nature remains neutral with regard to jurisdictional claims in published maps and institutional affiliations. 